\title{
Studies on water quality changes in River Nile and electric power plants treatment water at different localities in River Nile.
}

1Feriala, A.Abd El-Hady;1 Zeinab,M.Kheiralla; 1 Shimaa, M Abd- Elsalam and 2 Shereen, M. Asker

1 Faculty of Women, Ain Shams University,Cairo, Egypt.

${ }_{2}$ Central chemical labs of Egyptian Elecricity Trasmition Company (EETC),Cairo, Egypt.

\begin{abstract}
:
The aim of this study was to determine the seasonal variations in physicochemical and bacteriological parameters between inlet River Nile water and filtration water of Shoubra ElKhiema (SH) and Damietta (D) electric power plants. Total organic carbon (TOC) ranged between the highest values of $29.55-18$ and the lowest values of $28.95-21 \mathrm{mg} / \mathrm{l}$ at (SH) and (D) River Nile water respectively. In filtration water, TOC ranged between 27.5-20- and 21.79 - $16 \mathrm{mg} / \mathrm{l}$ at (SH) and (D) filtration water respectively. Mean of electric conductivity values exceeded permissible limit $417 \mathrm{mg} / \mathrm{l}$ at (D) River Nile but it still within limits of filtration water at two plants. Sulphate mean values ranged between $39.5,43$ and $19.7,26 \mathrm{mg} / \mathrm{l}$ at (SH) and (D) River Nile water respectively and it increased in filtration water to 77, 56 and 34, $41 \mathrm{mg} / \mathrm{l}$ at $(\mathrm{SH})$ and $(\mathrm{D})$ respectively, than permissible limits at two plants. The bacteriological analyses recorded the highest values of TC, FC, FS and Pseudomonas sp. during summer at inlet River Nile of two plants, but decreased in filtration water at two plants.
\end{abstract}

Key words: Physicochemical, bacteriological parameters, River Nile, Filtration water.

\section{1-INTRODUCTION}

River Nile constitutes over $90 \%$ of fresh water resources of Egypt. It is the main source of drinking water besides its use for agriculture, industry, recreation, fish production and in the electricity generation. During recent decades a considerable increase in pollution has taken in the rate of disposal of agricultural and domestic sewage into River Nile and its branches (Nehad and Shawky, 2013) which affects its physicochemical and microbiological quality (Chemmattu et al.,2014). In fact, the electricity production in a thermal power plant is based on a set of energies transformations using water as support of energy (Lakhoua1, 2013). The operation of the energetic boilers depends to a great extent on the quality of the water used for producing the steam (Nicolae, 2012). This water must have a noble quality to guarantee the installation security and to improve production groups' performances. It is therefore necessary to apply a rigorous

Corresponding author: at: Department of Botany, Faculty of Science, Faculty of women, Ain Shams University Egypt, Feriala et al., 2015. 
treatment of the raw water and a stern control of its quality (Lakhoua1, 2013) by processes such as filtration, softening and demineralization (Thamer and Usama, 2010). The degree of treatment depends on the nature of the river water (Singh et al., 2010). Bacteria have been recently categorized as aquatic plankton after recognizing that they play an important role in secondary production via bacterial primary production. For energy and material cycling, bacteria have been emphasized much because of their abundance and per unit higher surface-volume ratio (Li et al., 2004).

The aim of this study was to determine the seasonal variations in physicochemical and bacteriological parameters between inlet River Nile water and filtration water of Shoubra El-Khiema (SH) and Damietta (D) electric power plants and compared to electric power plants permissible limits.

\section{2-Materials and methods:}

\subsection{Study area and sampling sites:}

Two electric power plants were studied, Shoubra-El-Khiema its site on El- Kaliubiya governorate and Damietta which presented on Damietta governorate.

Table (1): Description of the study electric power plants:

\begin{tabular}{|c|l|l|}
\hline Plants & Shoubra El-Khiema power plant & Damietta power plant \\
\hline Power & $1200 \mathrm{M} \mathrm{W.}$ & $1230 \mathrm{M} \mathrm{W}$. \\
\hline $\begin{array}{l}\text { Intake } \\
\text { water }\end{array}$ & River Nile, the main stream. & Damietta branch. \\
\hline
\end{tabular}

\subsection{Water sampling:}

Eight inlet River Nile waters during (autumn 2010 to winter 2012) and four filtration water during (autumn 2011 to winter 2012) samples from each electric power plant Shoubra El-Khiema (SH) \& Damietta (D) Fig. (1) were collected seasonally according to the standard methods for the examination of water and wastewater (APHA, 2005).

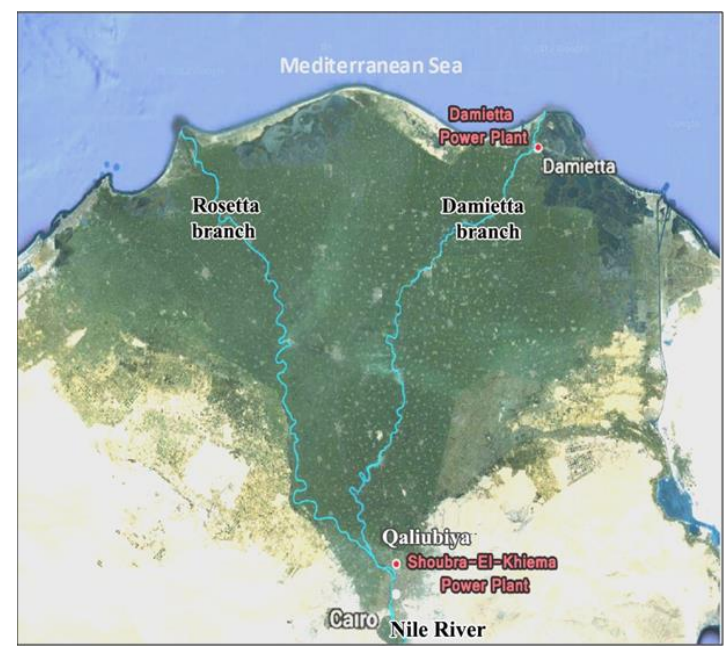

Fig. (1): Distribution of Shoubra El-Khiema power plant and Damietta electric power plant on River Nile (google earth). 


\subsection{Physicochemical analysis:}

Air and water temperature, $\mathrm{pH}$, total Alkalinity $(\mathrm{M})$, partial alkalinity $(\mathrm{P})$, total hardness, calcium hardness and magnesium hardness, were determined according to American Society for Testing and Materials (ASTM 2009). Total dissolved solids (TDS) and total suspended solids (TSS) were determined gravimetrically (APHA, 2005). Electrical conductivity (EC), turbidity(ASTM 2009), dissolved oxygen (DO) was determined by Azide Modification of Winkler Method, biochemical oxygen demand (BOD), chemical-oxygen demand (COD) was determined according to closed reflux colorimetric method(APHA, 2005), chlorides $(\mathrm{mg} / \mathrm{l})$ of water was determined according to Mohr's method, (ASTM 2009).Total-Organic Carbon (mg/l as Carbon) was determined as non-purgeable organic carbon (NPOC) by using Multi N/CUVHS instrument. Dissolved Silicon was determined according to colorimetric molybdate blue method, iron and ammonia were determined by using thermo scientific spectrophotometer (ASTM, 2009). Sodium and potasium, sulphate, nitrite, nitrat, phosphate were determined by using ion chromatography, Heavy metals were measured by Atomic Adsorption (ASTM, 2009).

\subsection{Bacteriological analysis:}

The heterotrophic plate count (HPC) at $22^{\circ} \mathrm{C}$ and $37^{\circ} \mathrm{C}$ were determined by using pour plate method. Total coliforms (TC), feacal coliforms (FC), feacal streptococci (FS), and Pseudomonas sp. were estimated by MPN method according to (APHA, 2005).

\subsection{Statistical Analysis:}

All River Nile values from physicochemical analyses and bacteriological are presented as mean \pm SD. Computer assisted data analysis were performed for determination of the correlation coefficients between the biological parameters and the physicochemical parameters through statistical program under excel windows according to Challejee (1995).

\section{3-RESULTS AND DISCUSION:}

Results of physicochemical characteristics of River Nile water showed in Table (1). Water temperature was always lower than the corresponding air temperature. Air and water temperatures were positively correlated during studied seasons $(r=1)$ (data not present). This indicated that the water temperature is affected thermal water pollution, this agree with Safaa et al. (2012).

The $\mathrm{pH}$ of River Nile water in all sites (Table 1) is within the South African Recommended Standard Limits (6.5-8.4) (Shawky and Saleh, 2007). Results of physicochemical characteristics of Filtration water was showed in Table (2). A lower $\mathrm{pH}$ values of filtration water influence of the added dose of aluminum sulphate than the $\mathrm{pH}$ values of River Nile water at the two investigated sites due to production of hydrogen ions, 
$\mathrm{H}_{3} \mathrm{O}^{+}$, during the hydrolysis of the aluminium sulphate ,this results agree with Badr El-Din (2012). PH was less than permission limits of filtration water at $\mathbf{D}$ electric power plant.

In table (1) the maximum total alkalinity (M) mean values of $145-150 \mathrm{mg} / \mathrm{l}$ were recorded during winter at SH and D River Nile respectively this can be attributed to the lower air and water temperature during cool season that affect the carbonate reactions (Abdo, 2005). Alkalinity exhibited negative correlation with water temperature $(r=-0.57)$ and high positive correlations with TDS and electric conductivity ( $r=0.86 \& 0.86$ respectively). Lower total alkalinity in filtration water than of River Nile water at the two investigated sites were due to add dose of aluminum sulphate which hydrolysed producing hydrogen ions that react with the alkalinity of the water leading to decrease the $\mathrm{pH}$ of the water (Ahmed, 2009).

The high $\mathrm{Ca}^{2+}$ concentration in River Nile Table (1) during autumn at $\mathbf{D}$ may be due to the re-dissolution of organisms and suspended solids containing $\mathrm{Ca}^{2+}$ in the presence of dissolved $\mathrm{CO}_{2}$ (Awdallah et al., 1991). Total Hardness in River Nile revealed negative correlation with temperature $(r=-0.79)$ and positive correlation with TDS $(r=0.70)$. Calcium and Magnesium hardness (data not present) of filtration water were the same as that of Nile water at the two investigated sites which may be due to the absence of the precipitation or adsorption through the treatment processes.

An increase of TDS values of $271.5-319 \mathrm{mg} / \mathrm{l}$ during winter at SH and $\mathbf{D}$ inlet River Nile water respectively Table (1), that may be related to lowering of water level in the River Nile during drought period which leads to concentrate the dissolved mineral in the water (Elsayed, 2009).At Damietta TDS increased permissible limits. In parallel to these findings, TDS and EC turbidity values revealed positively strong correlation to each other $(r=+0.97)$ as illustrated in (Mohamed and Mostafa, 2009) reported the same correlations. The increasing in total dissolved solids in filtration water (Table 2) than River Nile water due to additional of chemical treatment except in winter and spring seasons at $\mathbf{D}$ filtration water. Correlation coefficient showed complete correlation between TDS and EC $(r=1)$ at two plants.

The maximum TSS values during summer at two plants inlet River Nile water respectively because of flood period that carry silts from Ethiopian land during summer seasons Table (1). Total suspended solids values are positively correlated with TOC and silica ( $r=0.77 \& 0.71$, respectively). A decrease in total suspended solids of filtration water (Table 2) were observed than River Nile water at the two electric power plants due to using of aluminium sulfate which form $2 \mathrm{Al}(\mathrm{OH})^{3}$ bonded to suspended particles, making them more likely to settle out in a coagulation process (El Karamany, 2010). Correlation coefficient showed negative correlation between TSS and TOC $(r=-0.90)$ at two plants filtration water.

The turbidity in the inlet River Nile water of $\mathbf{S H}$ was higher than that of the inlet River Nile water of $\mathbf{D}$ power plant in autumn and summer (Table 1). This may be due to the 
industrial discharges in $\mathbf{S H}$ region Increasing values from up-stream to down-stream along the branch may be attributed to drains discharge (Safaa et al., 2012). Turbidity values were positively correlated with TC, FC, FS, Pseudomonas sp. ( $r=0.5)$, and with TOC ( $r=0.33)$. A decreasing of turbidity (Table 2) were observed after treatment of Nile water at the two investigated sites with aluminum sulfate, in addition, the particles are partly removed in the rapid sand filter, this results agree with Pontius (1990).

The high mean values of electric conductivity $428-495 \mu \mathrm{mho} / \mathrm{cm}$ (Table 1 ) at $\mathbf{S H}$ and D River Nile during winter respectively may be attributed to the intrusion of the drain's effluents into the lowered level water in the branch causing elevation of dissolved and suspended particles which increase the ability to convey electrical current (Ahmed, 2012). Conductivity values were positively correlated with $\mathrm{TOC}, \mathrm{Cl}^{-}$and $\mathrm{SO}_{4}^{-2}(r=0.80,0.66$ \&0.79, respectively), this results agree with Mohamed and Mostafa (2009). The seasonal average value of the electric conductivity of $\mathbf{D}$ was higher than the corresponding stations standard limits of River Nile but in SH the electric conductivity was within the limits. An increase in electrical conductivity of filtration water (Table 2) due to additional of chemical treatment. But in winter and spring seasons at $\mathbf{D}$ filtration water the electrical conductivity decrease which may be related to the dose used.

Table (1) showed that the dissolved oxygen mean values recorded the maximum values of $8.8-9.6 \mathrm{mg} / \mathrm{l}$ at $\mathbf{S H}$ and $\mathbf{D}$ inlet River Nile water respectively during winter may be due to the high solubility of oxygen at low water temperature (Saad et al. 2011). Dissolved oxygen values were negatively correlated with water temperature $(r=-0.48)$, similar results were obtained by Shehata and Badr (2010) and were negatively correlated with TC,FC,FS, Pseudomonas sp. $(r=-0.2)$. Decreasing in dissolving oxygen values after treatment (Table 2 ) at both electric power plants were due to removing a density of phytoplankton after water treatment process. But DO increased at autumn after treaetment may be fouling of sand filter with phytoplankton.

The maximum BOD values were 3.3-5 mg/l (Table 1) was recorded at SH and D River Nile during autumn and winter respectively, this agree with Mohamed et al. (2011), where concentrations were larger during low flow condition. This confirmed by statistical analysis ( $r$ $=-0.16,-0.21,-0.26 \&-0.25$ of TC,FC,FS and Pseudomonas sp. respectively) and between BOD. A decreased of BOD of filtration water (Table 2) than that of River Nile water at two plants may be due to the decreasing counts of microorganisms after treatment water process and adding of chlorine as disinfectants.

The high values of COD during spring at $\mathbf{D}$ inlet River Nile water (Table 1) could be attributed to the increase in water temperature which accelerates the oxidation of organic matter and decrease in oxygen content (Abdo, 2010). But the increased in autumn at $\mathbf{S H}$ may be due to increased of chemical wastes in drought period. Chemical oxygen demand 
gave a negative correlation with TOC ( $r=-0.49)$ and positive correlations with sulfate, nitrate and ammonia ( $r=0.60,0.71 \& 0.70$ respectively). The COD at $\mathbf{S H}$ of filtration water ranged from 1 to $4.8 \mathrm{mg} / \mathrm{l}$ during summer and spring respectively, while at $\mathbf{D}$ filtration water it ranged between $2-4.8 \mathrm{mg} / \mathrm{l}$ during autumn or summer and winter respectively (Table 2 ). The reduction in COD in filtration water may be due to chemical coagulation and membrane filtration methods (Nor and Wan, 2010).

The high value of TOC in River Nile during summer (Table 1) may be mainly related to flood water originating from Ethiopin highland which is known by its high turbidity due to silt carried (carbon source) that decomposed during high flow downstream special during hot summer. Statistically, the total organic carbon in Nile water was positively correlated with temperature $(r=70)$. The introduction of excess of organic matter may result in a depletion of oxygen from an aquatic system mainly during warm stagnant condition (Maria et al., 2000). Increasing of TOC during autumn (Table 2) at SH might be due to fouling of filtration medium. The chemical disinfection reaction with organic matter can also lead to an increase in organic carbon (Roeder et al., 2010).

As given in Table (1) the chloride mean values recorded the highest values ranged from 45.5 to $54.5 \mathrm{mg} /$ / during winter at $\mathbf{S H}$ and $\mathbf{D}$ inlet River Nile water respectively which were registered in cold seasons especially during the drought period, these results agreed with Metawea (2009). Chloride was negatively correlated with temperate $(r=-0.90)$ and was positively correlated with conductivity and sulphate ( $r=0.8 \& 0.9$ respectively). The increasing in chloride values after treatment (Table 2) was due to addition of disinfection in chlorination process.

Data in Table (1) showed the River Nile maximum sulphate content were 39.5 - 43 $\mathrm{mg} / \mathrm{l}$ measured at SH and $\mathbf{D}$ inlet River Nile water respectively during winter which were registered in cold seasons especially during the drought period (Metawea, 2009). Sulphate are positive correlated with total alkalinity, TSS, conductivity $(r=0.79)$ and sodium $(r=0.81)$ and were negatively correlated with silica $(r=-0.89)$. Table (2) showed filtration water sulphat values which varied between the maximum values of 77-56 during autumn and winter at $\mathbf{S H}$ and $\mathbf{D}$ filtration water respectively and the minimum values of $34-41 \mathrm{mg} / \mathrm{I}$ during summer at $\mathbf{S H}$ and $\mathbf{D}$ filtration water respectively. The maximum values were exceeded the stations permissible limits. The increasing of sulphate in filtration water than in raw water was a result of addition of chemical treatment (aluminum sulphate) this agree with Badr (2012).

The highest sodium mean values Table (1) were 92.5 -106.5 mg/l recorded during autumn and winter at $\mathbf{S H}$ and $\mathbf{D}$ inlet River Nile water respectively which exceeded the permissible limits. Major cations $\left(\mathrm{Ca}^{2+}, \mathrm{Mg}^{2+}, \mathrm{K}^{+}\right.$, and $\left.\mathrm{Na}^{+}\right)$are naturally very variable in environmental water due to local geological climate, geographical conditions and waste 
water discharge (Badr et al ., 2006). Table (2) showed that, the sodium concentration at SH filtration water ranged from 50 to $94.5 \mathrm{mg} / \mathrm{l}$ during summer and autumn respectively, while at $\mathbf{D}$ filtration water it ranged between $65-100 \mathrm{mg} / \mathrm{l}$ in spring and winter respectively. The average values were exceeded $\mathbf{D}$ permissible limits. Sodium concentration in filtration water did not change than that in River Nile water.

Potassium values Table (2) in filtration water were approximately did not change than that in River Nile water.

The high Fe mean values in River Nile (Table 1) during spring at SH may be attributed to low values of DO which promote reduction in the above equilibrium. So, Iron occurs as $\mathrm{Fe}$ ${ }^{2+}$ and wasn't precipitated as $\mathrm{Fe}(\mathrm{OH})^{3}$. The iron values Table (2) were found to be below permissible limits of $\mathbf{D}$ filtration water. Iron values in filtration water were less than in River Nile water which might be because the filtration process removed most of iron and after chlorination practically all of iron was oxidized (Keith et al., 2000).

The present data Table (1) showed high concentration of dissolved silica in River Nile occurred during the flood seasons in summer at SH River Nile water. The increase in silicon during the flood season was due to production of large Si reserves by rock weathering whose dissolution by the rain, temperature and turbulence of the river in flood (Hall et al., 1977). Silica was positively correlated with TSS and TOC ( $r=0.71 \& 0.65$, respectively). Silica values of filtration water Table (2) were less than in River Nile water due to coagulation, precipitation and filtration processes in treatment water.

Nitrite in River Nile Table (3) was positively correlation with ammonia ( $r=90)$. Nitrate mean values in River Nile Table (1) were in the permissible limits of SH power plant but exceeding permissible limits of $\mathbf{D}$ power plant. Increases of $\mathrm{NO}_{3}{ }^{-}$and decreases in $\mathrm{NH}_{4}{ }^{+}$have been identified as an increase towards north (Nile downstream) in which oxidation of ammonia $\left(\mathrm{NH}_{3}\right)$ to nitrate $\left(\mathrm{NO}_{3}\right)$ and nitrite $\left(\mathrm{NO}_{2}\right)$ by aerobic bacteria in a process called nitrification (Safaa et al., 2012). Phosphorus was positively correlated with COD ( $r=0.71)$. As showed in Table (2) nitrite, nitrate and phosphate were not detected in most seasons at two plants filtration water. Nitrite, nitrate and phosphate in filtration water were nearly the same or less than River Nile water.

From Table (1) it was found that ammonia was recorded a low concentration during all seasons at River Nile. Ammonia was positively correlated with HPC at $22^{\circ} \mathrm{C}$ and HPC at $37^{\circ} \mathrm{C}(r=0.90)$. Ammonia values in filtration water Table (2) were, nearly, the same or demolished than in River Nile water that might be due to the effect of chlorination with ammonia,this agree with Badr (2012).

As showed in Table (1), trace element in SH River Nile of $\mathrm{Mn}$ ranged from $<0.001$ to 0.0008 and $\mathrm{Zn}$ fluctuated between $<0.001$ and $0.00043 \mathrm{mg} / \mathrm{l}$. Some of heavy metals ( $\mathrm{Zn}, \mathrm{Ni}$, 
and $\mathrm{Mn}$ ) were enriched during the treatment process (Table 2). This could be attributed to the adsorption of these metals by the organic matter retained in these filters during low discharge rates. Under such conditions, some of the former precipitated Fe-oxihydroxides may be dissolved and release their adsorbed heavy metal load into the water (Geriesh et al., 2004).

As showed in Table (3), the highest bacterial counts (HPC) in River Nile were recorded for both groups (at $22^{\circ} \mathrm{C}$ and $37^{\circ} \mathrm{C}$ ) during spring for both power plants. This might be due to the high temperature prevailing during this season and discharged wastewater during this season. Damietta inlet River Nile water bacterial counts at both incubation temperatures $\left(22^{\circ} \mathrm{C}\right.$ and $\left.37^{\circ} \mathrm{C}\right)$ almost higher than that at $\mathbf{S H}$. This may reflects the nature of heterotrophic bacteria and the density of fecal pollution (Wafaa, 2006). As showed in Table (4), a decrease in HPC counts at both $22^{\circ} \mathrm{C}, 37^{\circ} \mathrm{C}, \mathrm{TC}, \mathrm{FC}, \mathrm{FS}$ and Pseudomonas sp. of filtration water than River Nile water. Although some variation in HPC levels is normal and can occur seasonally, these increases can indicate a change in raw water quality, problems with water treatment, or problems in the distribution system or plumbing and should be investigated (Federal, 2012).

The bacterial values in River Nile (Table 3) detected in warmer seasons. They reached their maximum values during summer when TC, FC, FS and Pseudomonas sp. recorded $143.5 \times 10^{3}-15.5 \times 10^{3}, 22 \times 10^{3}-8 \times 10^{3}, 3.6 \times 10^{3}-0.66 \times 10^{3}, 0.2 \times 10^{3}-7.6 \times 10^{3} \mathrm{MPN} / 100 \mathrm{ml}$ at SH and $\mathbf{D}$ respectively, These results may be due to increase of water temperature and discharge of waste water during these seasons (Sabae and Rabeh, 2007). Statistical analysis indicated highly positive significant correlation ( $r=+0.9)$ between different bacteriological parameters (HPC, TC, FC and FS) at River Nile. The same results were concluded by (Safaa et al., 2012) and negative correlation with $D O(r=-0.2)$.

Richard (2004) reported that, the presence of coliforms in water distribution systems associated with biofilm growth problems, inadequate treatment, cross-connections or failure to maintain an adequate disinfectant residual.As observed in Table (4), Faecal Streptococci presented in filtration water during autumn at $\mathbf{S H}$ and presented during all seasons except during winter at $\mathbf{D}$ in contrasted with faecal coliform not presented at those seasons at two plants. Faecal streptococci are rarely multiply in polluted water (Amira et al., 2012). The presence of Pseudomonas sp. during autumn and winter at SH (Table 4) might be due to fouling filtration medium with high concentration of organic matter which lead to low rats of flow leading to multiply of Pseudomonas sp. during distribution given suitable conditions (Hunter, 1997). 


\section{4-CONCLUSIONS:}

Water quality along the studied areas in SH and D inlet Nile River influenced by wastewater discharge from regarding both physicochemical and bacteriological characteristics. After treatment, TC,FC, FS and Pseudomonas sp. was decreased but still existing also increased of sulphate in filtration water than River Nile water. The presence of any impurities in the filtration water affects on the performance of anion exchange resin and water quality produced which leading to deposits layers and forms corrosion on boiler and turbines in the electric power plants, so it affects on the electricity production.

\section{5-RECOMMEDATIONS:}

Monitoring of Nile River water regularly and constantly should be followed up in order to record any alteration in quality and the detrimental impacts on the aquatic ecosystem and for water treatment effectiveness. Adequate records of coagulation dose chlorine additions and measurements as well as indicator bacteria monitoring should be kept. 
J. Sci. Res. Sci.,Vol.(32), part:1,

Table (1) The variation of physicochemical parameters of inlet River Nile water of Shoubra El- Khiema and Damietta electric power plants at different seasons (Autumn 2010- Winter 2012):

\begin{tabular}{|c|c|c|c|c|c|c|c|c|c|c|}
\hline Seasons & Aut & umn & Wir & & Spr & ing & Sur & nmer & Statio & Limits \\
\hline 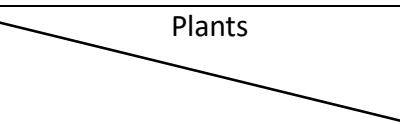 & $\begin{array}{l}\text { Shoubra } \\
\text { El-khiema }\end{array}$ & Damietta & $\begin{array}{c}\text { Shoubra El- } \\
\text { Khiema }\end{array}$ & Damietta & $\begin{array}{l}\text { Shoubra } \\
\text { El-khiema }\end{array}$ & Damietta & $\begin{array}{l}\text { Shoubra } \\
\text { El-khiema }\end{array}$ & Damietta & $\begin{array}{l}\text { Shoubra } \\
\text { El-khiema }\end{array}$ & Dam \\
\hline meters & Mean \pm SD & Mean \pm SD & Mean \pm SD & Mean $\pm S D$ & Mean \pm SD & Mean \pm SD & Mean $\pm S D$ & Mean $\pm S D$ & & \\
\hline perature $\mathrm{C}^{\circ}$ & $25 \pm 0$ & $19.5 \pm 2.5$ & $23 \pm 0$ & $25 \pm 0$ & $31.5 \pm 6.5$ & $30 \pm 5$ & $35 \pm 3$ & $36 \pm 2$ & - & - \\
\hline water & $23 \pm 0$ & $17.5 \pm 2.5$ & $19 \pm 0$ & $24 \pm 0$ & $29 \pm 7$ & $29 \pm 5$ & $33.5 \pm 2.5$ & $34 \pm 2$ & $14-29$ & $14-3$ \\
\hline & $8.3 \pm 0$ & $7.71 \pm 0.19$ & $8.21 \pm 0.01$ & $7.86 \pm 0.49$ & $7.84 \pm 0.32$ & $7.89 \pm 0.11$ & $7.75 \pm 0.15$ & $8.05 \pm 0.65$ & $7.4-8.3$ & $7.4-\varepsilon$ \\
\hline Alkalinity $\mathrm{mg} / \mathrm{Las} \mathrm{CaCO}_{3} \mathbf{~ M}$ & $1.25 \pm 1.25$ & $0 \pm 0$ & $0 \pm 0$ & $0 \pm 0$ & $0 \pm 0$ & $0 \pm 0$ & $0 \pm 0$ & $0 \pm 0$ & - & \\
\hline cial alkalinity & $135 \pm 10$ & $145 \pm 0$ & $145 \pm 0$ & $150 \pm 5$ & $133.8 \pm 3.8$ & $137.5 \pm 7.5$ & $120 \pm 5$ & $132.5 \pm 7.5$ & $<175$ & 112 \\
\hline ardness $\mathrm{mg} / \mathrm{L}$ as $\mathrm{CaCO}_{3}$ Total $\mathbf{~ H}$ & $114 \pm 14$ & $143.5 \pm 11.5$ & $128.5 \pm 3.5$ & $137.5 \pm 2.5$ & $112.5 \pm 2.5$ & $121 \pm 1$ & $105 \pm 0$ & $112.5 \pm 7.5$ & $84-140$ & $65-$ \\
\hline Ca H. & $62 \pm 7$ & $88 \pm 6$ & $72 \pm 5$ & $83.5 \pm 6.5$ & $65 \pm 5$ & $75 \pm 0$ & $66 \pm 0$ & $70 \pm 5$ & $<95$ & $44-9$ \\
\hline $\mathrm{Mg} \mathrm{H}$. & $52 \pm 7$ & $55.5 \pm 5.5$ & $56.5 \pm 1.5$ & $54 \pm 4$ & $47.5 \pm 2.5$ & $46 \pm 1$ & $39 \pm 0$ & $42.5 \pm 2.5$ & $<75$ & 21 \\
\hline I dissolved solid mg/L & $264 \pm 36$ & $275.8 \pm 10$ & $271.5 \pm 31.5$ & $319.5 \pm 22.5$ & $238.5 \pm 11.5$ & $248.8 \pm 17.75$ & $219.5 \pm 18.5$ & $266.35 \pm 22.65$ & $125-300$ & 135 \\
\hline suspended solid $\mathrm{mg} / \mathrm{L}$ & $6.2 \pm 1.8$ & $5.8 \pm 0.2$ & $6.65 \pm 0.35$ & $6.8 \pm 0.2$ & $6.25 \pm 1.25$ & $5.85 \pm 0.15$ & $16 \pm 4$ & $7.65 \pm 0.35$ & $<30$ & 1- \\
\hline jidity NTU & $3.05 \pm 1.95$ & $2.95 \pm 1.55$ & $3.25 \pm 0.05$ & $3.25 \pm 0.25$ & $3.1 \pm 0.4$ & $3.1 \pm 0.5$ & $4.8 \pm 1.7$ & $2.65 \pm 0.45$ & $<11$ & $4.4-$ \\
\hline $\mathrm{us} / \mathrm{cm}$ & $395 \pm 45$ & $424 \pm 16$ & $428 \pm 20$ & $495 \pm 35$ & $367.5 \pm 17.5$ & $390 \pm 20$ & $364 \pm 2$ & $403 \pm 28$ & $190-450$ & $190-$ \\
\hline $\mathrm{ng} / \mathrm{l}$ & $8.3 \pm 1.3$ & $7.7 \pm 1.7$ & $8.8 \pm 0.2$ & $9.6 \pm 4$ & $7.01 \pm 1.41$ & $8.4 \pm 1$ & $7.65 \pm 0.25$ & $7.4 \pm 0.6$ & $>5^{*}$ & $>5$ \\
\hline $\mathrm{mg} / \mathrm{l}$ & $3.3 \pm 0.9$ & $1.51 \pm 0.19$ & $3 \pm 0.4$ & $5 \pm 3.8$ & $2.71 \pm 0.91$ & $4.27 \pm 0.53$ & $2.6 \pm 0.4$ & $1.45 \pm 0.05$ & $<6-10^{*}$ & $<6-1$ \\
\hline $\mathrm{mg} / \mathrm{l}$ & $9.75 \pm 2.75$ & $8 \pm 0$ & $6.75 \pm 1.75$ & $6.65 \pm 1.65$ & $5.65 \pm 0.65$ & $8.2 \pm 3.2$ & $5.63 \pm 0.63$ & $5.15 \pm 0.85$ & $<10-15^{*}$ & $<10-$ \\
\hline organic carbon $\mathrm{mg} / \mathrm{l}$ as $\mathrm{C}$ & $18 \pm 3$ & $21.5 \pm 0.5$ & $25 \pm 1$ & $24 \pm 1$ & $24.03 \pm 0.98$ & $27.85 \pm 1.85$ & $29.55 \pm 1.55$ & $28.95 \pm 4.05$ & - & - \\
\hline $\mathrm{mg} / \mathrm{l}$ & $40 \pm 5$ & $50.5 \pm 4.5$ & $45.5 \pm 3.5$ & $54.5 \pm 5.5$ & $25.6 \pm 2.6$ & $30.5 \pm 0.5$ & $22 \pm 4$ & $32.9 \pm 0.9$ & $<43$ & $40-\varepsilon$ \\
\hline $2 \mathrm{mg} / \mathrm{l}$ & $35.3 \pm 4.7$ & $39 \pm 4$ & $39.5 \pm 1.5$ & $43 \pm 1$ & $25.8 \pm 4.8$ & $26.4 \pm 4.6$ & $19.7 \pm 0.3$ & $26 \pm 5$ & $12.5-41.6$ & $14-4$ \\
\hline $\mathrm{mg} / \mathrm{l}$ & $92.5 \pm 2.5$ & $84.5 \pm 14.5$ & $91.5 \pm 2.5$ & $106.5 \pm 6.5$ & $69 \pm 2$ & $70.5 \pm 5.5$ & $52 \pm 2$ & $75.95 \pm 2.05$ & $32.5-70.2$ & $32-7$ \\
\hline $\mathrm{mg} / \mathrm{l}$ & $6.5 \pm 0.5$ & $6 \pm 0$ & $6 \pm 0$ & $7 \pm 0$ & $7.5 \pm 2.5$ & $6.5 \pm 1.5$ & $5.75 \pm 0.25$ & $6.6 \pm 0.4$ & - & - \\
\hline $\mathrm{mg} / \mathrm{l}$ & $0.04 \pm 0.02$ & $0.03 \pm 0.01$ & $0.04 \pm 0.02$ & $0.04 \pm 0.02$ & $0.13 \pm 0.06$ & $0.06 \pm 0.01$ & $0.04 \pm 0.00$ & $0.04 \pm 0.01$ & $0.085-0.5$ & 0.08 \\
\hline
\end{tabular}


J. Sci. Res. Sci.,Vol.(32), part:1,

2015

\begin{tabular}{|c|c|c|c|c|c|c|c|c|c|c|}
\hline $\mathrm{a} \mathrm{mg/l}$ & $0.22 \pm 0.19$ & $2.05 \pm 0.75$ & $0.34 \pm 0.09$ & $0.54 \pm 0.36$ & $2.6 \pm 0.3$ & $2.51 \pm 0.19$ & $4.8 \pm 2.1$ & $2.1 \pm 0.9$ & $<18$ & $0.6-$ \\
\hline $\mathrm{mg} / \mathrm{l}$ as $\mathrm{No}_{2}^{-}$ & ND & ND & ND & ND & ND & $0.06 \pm 0.05$ & ND & ND & $0.06-0.4$ & - \\
\hline $\mathrm{mg} / \mathrm{l}$ as $\mathrm{No}_{3}^{-}$ & $0.32 \pm 0.28$ & ND & $0.18 \pm 0.17$ & $2.16 \pm 2.15$ & ND & $0.61 \pm 0.60$ & ND & ND & - & 0.06 \\
\hline $3 \mathrm{mg} / \mathrm{l}$ as $\mathrm{PO}_{4}^{-3}$ & $0.04 \pm 0.03$ & ND & ND & ND & ND & ND & ND & ND & - & - \\
\hline$+\mathrm{mg} / \mathrm{l}$ as $\mathrm{NH}_{3}{ }^{+}$ & ND & $0.25 \pm 0.25$ & ND & ND & $0.51 \pm 0.5$ & $0.06 \pm 0.05$ & ND & ND & - & - \\
\hline $\mathrm{mg} / \mathrm{l}$ & ND & ND & $0.0008 \pm 0.0003$ & ND & ND & ND & ND & ND & - & - \\
\hline $\mathrm{mg} / \mathrm{l}$ & ND & ND & $0.0043 \pm 0.00017$ & ND & ND & ND & ND & ND & - & - \\
\hline
\end{tabular}

SD,Standard deviation,-,No guideline available, Cond., conductivity, P, partial alkalinity, $\mathrm{M}$, total alkalinity, Ca $\mathrm{H}$., calcium hardness, $\mathrm{MgH}$. , Magnesium hardness.ND, not detected ,The trace element values of $\mathrm{As}, \mathrm{Cr}, \mathrm{Cu}, \mathrm{Ni}, \mathrm{Cd}, \mathrm{Pb}, \mathrm{Co}$ and $\mathrm{Hg}$ were not detected at both electric power plants, ${ }^{*}$, according to law 48/1982.

Table (2) The variation of physicochemical parameters of Filtration water of Shoubra El- Khiema and Damietta electric power plants at different seasons (Autumn 2011- Winter 2012):

\begin{tabular}{|c|c|c|c|c|c|c|c|c|c|c|}
\hline Seasons & \multicolumn{2}{|c|}{ Autumn } & \multicolumn{2}{|c|}{ Winter } & \multicolumn{2}{|c|}{ Spring } & \multicolumn{2}{|c|}{ Summer } & \multicolumn{2}{|c|}{ Stations Limit: } \\
\hline $\begin{array}{l} \\
\end{array}$ & $\begin{array}{c}\text { Shoubra } \\
\text { El- } \\
\text { Khiema }\end{array}$ & Damietta & $\begin{array}{c}\text { Shoubra } \\
\text { El- } \\
\text { Khiema }\end{array}$ & Damietta & $\begin{array}{c}\text { Shoubra } \\
\text { El- } \\
\text { Khiema }\end{array}$ & Damietta & $\begin{array}{c}\text { Shoubra } \\
\text { El- } \\
\text { Khiema }\end{array}$ & Damietta & $\begin{array}{c}\text { Shoubra } \\
\text { El- } \\
\text { Khiema }\end{array}$ & Dami \\
\hline & 7.6 & 7.43 & 7.59 & 6.84 & 7.6 & 7.6 & 7.45 & 6.8 & $7.4-8.3$ & $7.4-\varepsilon$ \\
\hline al Alkalinity $\mathrm{mg} / \mathrm{Las} \mathrm{CaCO}_{3} \mathbf{M}$ & 0 & 0 & 0 & 0 & 0 & 0 & 0 & 0 & - & \\
\hline tial alkalinity & 95 & 135 & 105 & 125 & 115 & 120 & 105 & 120 & $<150$ & $112-$ \\
\hline dness $\mathrm{mg} / \mathrm{L}$ as $\mathrm{CaCO}_{3}$ Total $\mathbf{H}$ & 120 & 132 & 132 & 135 & 115 & 122 & 105 & 120 & $84-140$ & $<17$ \\
\hline $\mathrm{CaH}$. & 75 & 82 & 77 & 77 & 65 & 75 & 66 & 75 & $<95$ & $44-$ \\
\hline Mg H. & 45 & 50 & 55 & 58 & 50 & 47 & 39 & 45 & $<75$ & 21- \\
\hline al dissolved solid mg/L & 267 & 283 & 275 & 298 & 250 & 245 & 243 & 283 & $125-300$ & $\begin{array}{l}13 ! \\
29\end{array}$ \\
\hline al suspended solid $\mathrm{mg} / \mathrm{L}$ & 1.2 & 3 & 2.7 & 2.3 & 3.6 & 2.5 & 2.6 & 1 & - & $4-$ \\
\hline oidity NTU & 0.4 & 1 & 0.9 & 1.2 & 1.2 & 1.1 & 0.7 & 0.8 & $<1$ & 0.5 \\
\hline
\end{tabular}


J. Sci. Res. Sci.,Vol.(32), part:1,

$-2015$

\begin{tabular}{|c|c|c|c|c|c|c|c|c|c|c|}
\hline$\mu \mathrm{s} / \mathrm{cm}$ & 425 & 446 & 436 & 474 & 394 & 379 & 380 & 446 & 190417 & 190 \\
\hline $\mathrm{mg} / \mathrm{l}$ & 5.5 & 8.4 & 3.8 & 8.6 & 5.66 & 7 & 6.4 & 6.7 & - & \\
\hline $\mathrm{mg} / \mathrm{l}$ & 0.7 & 0.9 & 2.2 & 4 & 1.87 & 1.86 & 0.7 & 0.15 & - & \\
\hline $\mathrm{mg} / \mathrm{l}$ & 1.5 & 2 & 3 & 4.8 & 4.8 & 4.14 & 1 & 2 & - & - \\
\hline al organic carbon $\mathrm{mg} / \mathrm{l}$ as $\mathrm{C}$ & 27.5 & 16 & 20 & 18.6 & 20.46 & 19.78 & 21.28 & 21.79 & - & - \\
\hline $\mathrm{mg} / \mathrm{l}$ & 45 & 55 & 55 & 55 & 33 & 31 & 26 & 36.6 & $<50$ & $40-$ \\
\hline$-2 \mathrm{mg} / \mathrm{l}$ & 77 & 45 & 76.5 & 56 & 40 & 42 & 34 & 41 & $<50$ & 14. \\
\hline $\mathrm{mg} / \mathrm{l}$ & 94.5 & 99 & 89 & 100 & 71.7 & 65 & 50 & 73.9 & - & $32-$ \\
\hline $\mathrm{mg} / \mathrm{l}$ & 8 & 6 & 6 & 7 & 5.6 & 5 & 5.5 & 7 & - & - \\
\hline $\mathrm{mg} / \mathrm{l}$ & ND & 0.04 & 0.04 & 0.02 & 0.04 & 0.04 & 0.03 & 0.03 & - & 0.085 \\
\hline $\mathrm{a} \mathrm{mg} / \mathrm{l}$ & 0.03 & 2.58 & 0.19 & 0.39 & 1.9 & 2.2 & 6.6 & 2.9 & $<13$ & 0.9 \\
\hline $\mathrm{mg} / \mathrm{l}$ as $\mathrm{No}_{2}^{-}$ & ND & ND & ND & ND & ND & ND & ND & ND & - & - \\
\hline $\mathrm{mg} / \mathrm{l}$ as $\mathrm{No}_{3}{ }^{-}$ & 0.003 & ND & ND & ND & ND & ND & ND & ND & - & 0.06 \\
\hline$-3 \mathrm{mg} / \mathrm{l}$ as $\mathrm{PO}_{4}^{-3}$ & 0.003 & ND & ND & ND & ND & ND & ND & ND & - & - \\
\hline${ }^{+} \mathrm{mg} / \mathrm{l}$ as $\mathrm{NH}_{3}{ }^{+}$ & ND & ND & ND & ND & 0.2 & ND & ND & ND & - & - \\
\hline $\mathrm{mg} / \mathrm{l}$ & ND & ND & 0.023 & ND & ND & ND & ND & ND & - & - \\
\hline $\mathrm{mg} / \mathrm{l}$ & ND & ND & 0.0226 & ND & ND & ND & ND & ND & - & - \\
\hline $\mathrm{mg} / \mathrm{l}$ & ND & ND & 0.0106 & ND & ND & ND & ND & ND & - & - \\
\hline
\end{tabular}

-, No guideline available, Cond., conductivity, P , partial alkalinity , M , total alkalinity, Ca H., calcium hardness, MgH., Magnesium hardness.

ND, not detected ,The trace element values of $\mathrm{As}, \mathrm{Cr}, \mathrm{Cu}, \mathrm{Cd}, \mathrm{Co}$ and $\mathrm{Hg}$ were not detected at both electric power plants. 
Table (3)The variation of bacteriological parameters of Inlet River Nile water at Shoubra El- Khiema and Damietta electric power plants at different seasons (Autumn 2010-Winter 2012):

\begin{tabular}{|c|c|c|c|c|c|c|c|c|}
\hline Seasons & \multicolumn{2}{|c|}{ Autumn } & \multicolumn{2}{|c|}{ Winter } & \multicolumn{2}{|c|}{ Spring } & \multicolumn{2}{|c|}{ Summer } \\
\hline Plants & $\begin{array}{l}\text { Shoubra } \\
\text { El- } \\
\text { Khiema }\end{array}$ & Damietta & $\begin{array}{l}\text { Shoubra } \\
\text { El- } \\
\text { Khiema }\end{array}$ & Damietta & $\begin{array}{l}\text { Shoubra } \\
\text { El- } \\
\text { Khiema }\end{array}$ & Damietta & $\begin{array}{l}\text { Shoubra } \\
\text { El- } \\
\text { Khiema }\end{array}$ & Damietta \\
\hline Parameters & Mean $\pm S D$ & Mean $\pm S D$ & Mean士SD & Mean $\pm S D$ & Mean士SD & Mean $\pm S D$ & Mean $\pm S D$ & Mean $\pm S D$ \\
\hline $\begin{array}{l}\mathrm{HPC} \text { at } 22^{\circ} \mathrm{C} \\
\left(\mathrm{CFU} / \mathrm{ml} \times 10^{3}\right)\end{array}$ & $0.7 \pm 0.157$ & $5.3 \pm 2.108$ & $1.7 \pm 1.417$ & $2.5 \pm 1.530$ & $2.4 \pm 1.595$ & $20.3 \pm 1.961$ & $1.4 \pm 0.185$ & $3.0 \pm 1.836$ \\
\hline $\begin{array}{l}\mathrm{HPC} \text { at } 37^{\circ} \mathrm{C} \\
\left(\mathrm{CFU} / \mathrm{ml} \times 10^{3}\right)\end{array}$ & $0.46 \pm 0.160$ & $2.1 \pm 0.133$ & $1.2 \pm 0.917$ & $1.36 \pm 0.570$ & $3.5 \pm 0.490$ & $87 \pm 78.250$ & $2 \pm 0.760$ & $5.1 \pm 4.426$ \\
\hline $\begin{array}{l}\text { TC } \\
\left(\mathrm{MPN} / 100 \mathrm{ml} \times 10^{3}\right)\end{array}$ & $16 \pm 8.050$ & $3 \pm 1.300$ & $4.3 \pm 3.630$ & $8.1 \pm 1.100$ & $58 \pm 34.000 *$ & $15.1 \pm 10.961$ & $\begin{array}{c}143.5 \pm \\
136.500 *\end{array}$ & $15.5 \pm 0.850$ \\
\hline $\begin{array}{l}\text { FC } \\
\left(\mathrm{MPN} / 100 \mathrm{ml} \times 10^{3}\right)\end{array}$ & $2.6 \pm 2.315$ & $0.13 \pm 0.037$ & $1.3 \pm 1.085$ & $0.3 \pm 0.130$ & $0.34 \pm 0.339$ & $1.1 \pm 1.089$ & $22 \pm 21.499$ & $8 \pm 7.999$ \\
\hline $\begin{array}{l}\text { FS } \\
\left(\mathrm{MPN} / 100 \mathrm{ml} \times 10^{3}\right)\end{array}$ & $0.165 \pm 0.164$ & $0.096 \pm 0.083$ & $0.065 \pm 0.045$ & $0.23 \pm 0.153$ & $0.245 \pm 0.244$ & $0.087 \pm 0.082$ & $3.6 \pm 3.365$ & $0.66 \pm 0.640$ \\
\hline $\begin{array}{l}\text { Pseudomonas sp. } \\
\left(\mathrm{MPN} / 100 \mathrm{ml} \times 10^{3}\right)\end{array}$ & $0.085 \pm 0.084$ & $\begin{array}{l}0.001 \pm \\
0.0006\end{array}$ & $0.145 \pm 0.025$ & $\begin{array}{r}0.012 \pm \\
0.00785\end{array}$ & $0.119 \pm 0.051$ & $0.132 \pm 0.083$ & $0.2 \pm 0.030$ & $7.6 \pm 7.599$ \\
\hline
\end{tabular}

SD, Standard deviation $\times 10^{3},-$, No guideline available, ${ }^{*}$ Increased the limits of $<25000$ according to law 48/1982.

Egyptian Law for protection of the River Nile and water ways from pollution. 
Table (4) The variation of physicochemical parameters of Filtration water of Shoubra

El- Khiema and Damietta electric power plants at different seasons (Autumn 2011Winter 2012):

\begin{tabular}{|c|c|c|c|c|c|c|c|c|}
\hline Seasons & \multicolumn{2}{|c|}{ Autumn } & \multicolumn{2}{|c|}{ Winter } & \multicolumn{2}{|c|}{ Spring } & \multicolumn{2}{|c|}{ Summer } \\
\hline Parameters & $\begin{array}{c}\text { Shoubra } \\
\text { El- } \\
\text { Khiema }\end{array}$ & Damietta & $\begin{array}{c}\text { Shoubra } \\
\text { El- } \\
\text { Khiema }\end{array}$ & Damietta & $\begin{array}{c}\text { Shoubra } \\
\text { El- } \\
\text { Khiema }\end{array}$ & Damietta & $\begin{array}{c}\text { Shoubra } \\
\text { El- } \\
\text { Khiema }\end{array}$ & Damietta \\
\hline $\begin{array}{l}\mathrm{HPC} \text { at } 22^{\circ} \mathrm{C} \\
(\mathrm{CFU} / \mathrm{ml})\end{array}$ & 18 & 90 & 117 & 0 & 32 & 620 & 3 & 400 \\
\hline $\begin{array}{l}\mathrm{HPC} \text { at } 37^{\circ} \mathrm{C} \\
(\mathrm{FU} / \mathrm{ml})\end{array}$ & 0 & 10 & 5 & 5 & 2 & 460 & 1 & 3000 \\
\hline TC (MPN/100ml) & 12 & $>23$ & 16.1 & 1.1 & 3.6 & 3.6 & 5.1 & $>23$ \\
\hline FC (MPN/100ml) & $<1.1$ & $<1.1$ & $<1.1$ & 1.1 & $<1.1$ & $<1.1$ & $<1.1$ & $<1.1$ \\
\hline FS (MPN/100ml) & 2.2 & 12 & $<1.1$ & $<1.1$ & $<1.1$ & 1.1 & $<1.1$ & 1.1 \\
\hline $\begin{array}{l}\text { Pseudomonas sp. } \\
\text { (MPN/100ml) }\end{array}$ & 2.2 & $<1.1$ & 3.6 & $<1.1$ & $<1.1$ & 6.9 & $<1.1$ & $<1.1$ \\
\hline
\end{tabular}

\section{6-Refrence}

Abdo, M.H. Physico-chemical characteristics of abu za'baal ponds. Egyptian Journal of Aquatic Research. 31: 1-15.Agricultural Policy Reform Program. 2002. Survey of Nile system pollution sources, 64:1-72 (2005).

Abdo, M.H. Environmental and water quality evaluation of Damietta branch, River Nile, Egypt. African Journal Biology. Science., 6(2): 143-158 (2010).

Ahmed, M.AL-S. Evaluation of Potable Water Quality of AL-Diwaniyah Water Treatment Plants, Kufa Journal of Engineering,1(1): p40-58 (2009).

Ahmed, N.A.M. Biochemical studies on pollution of the River Nile at different stations of Delta barrage (Egypt). Ph.D. Thesis, faculty. Agriculture., Benha University, Egypt (2012).

Amira, M. E.; Abdel, M. E.; Sulieman and Elamin, A. E. Microbiological assessment of drinking water quality in Wad-Medani \&Khartoum states, Sixteenth International Water Technology Conference, IWTC 16 2012, Istanbul, Turkey,1-13 (2012). 
APHA, A. D. Eaton. American Public Health Association, Mary Ann H. Franson, American Water Works Association (Edition),Standard Methods for the Examination of Water \& Wastewater,(2005).

ASTM. American Society for Testing and Materials, West Conshohocken,PA. (2009).

Awadallah, R. M.; El-Haty, M. T.; Soltan, M. E.and Ahmed, I.A. Characterization of the Nile water quality in the zone from Aswan to Giza. J.Sci. 15(1): 84-104(1991).

Badr El-Din E. H. Comparative Study of Different Water Treatment Plants in Damietta Governerate, Egypt, Australian Journal of Basic and Applied Sciences, 6(3): 474-482 (2012).

Badr, .M.H..;Abdelsamie, E.; Mohammed, B.S.; Laila, F.M. and Ghada, S. A. Studies on the effect of El Rahawy drain on the River Nile water pollution by trace metals and major cations at El-Kanater-El Khyria area under the effect of seasonal variation, Ass. University Bull. Environ. Research. ,9 (2): p35-53 (2006).

Chatterjee, S. and $\mathbf{M}$ "achler, $\mathbf{M}$. Robust regression: A weighted least squares approach. Communications in Statistics, Theory and Methods, 26: 1381-1394 (1995).

Chemmattu, M. M. , Puzhakkal U. M. and Puthenveedu S. P.H. (2014). Isolation and characterisation of Total Streptocci and Faecal Streptococci from Kuppam river basin in South west coast of India, International .Journal. Curr. Microbiology. Applied Science 3(3): 164-175 (2014).

Egyptian Law 48/1982. The Implementer Regulations for law 48/1982 regarding the protection of the River Nile and water ways from pollution,Periodical Bull. 3-4: 12-35(1982).

El-Karamany, .H. Study for industrial wastewater treatment using some coagulants, Fourteenth International Water Technology Conference, IWTC 14 2010, Cairo, Egypt, 283-291 (2010).

Elsayed, E.E. (2009). Modulation of respiratory functions of blood in response to the agricultural and industrial pollution of River Nile in Tilapia "Oreochromis niloticus", M.SC. Thesis. faculty, of Science, Benha University, Egypt (2009).

Federal-P. Guidance on the Use of Heterotrophic Plate Counts in Canadian Drinking Water Supplies, Health Canada Ottawa, Ontario K1A 0K9, Catalogue No. H144-6/2013E-PDF,1-13 (2012).

Geriesh, M.H., Stueben, D., Berner, Z., Ibraheim, M. (2004). Deficiencies of Simple Technologies in Surface Water Purification: A Case Study of Surface Water Treatment for Drinking Purposes at Suez City, Egypt. The 7th International Conference of Geology of Arab World (GAW 7).Cairo, Egypt, p.429-437 (2004).

Hall, A.; Valente, I. and Davies, B.R. (1977). The Zambezi River in Moçambique: The physicochemical status of the middle and lower Zambezi prior to the closure of the Cabora Bassa dam. Freshwater. Biology. 7: 187-206 (1977). 
Hunter P.Waterborne Disease. Epidemiology and Ecology.Chichester:Wiley,England(1997).

Keith, F.; Abraham, C.; Lili, W. Arsenic removal from drinking water by iron removal plants, U.S. Environmental Protection Agency, EPA (2000).

Lakhoua. M.N. (2013). Programming and visualizing the chemical analysis parameters of the water steam cycle, Journal of Electrical Engineering, 13/1013 edition3: 1-6 (2013).

Li, W.K.W.; Erica, J.H.H. and Harrisonm, W.G. Macroecological limits of heterotrophic bacterial abundance in the ocean. Deep-Sea Research, 51: 1529-1540 (2004).

Maria A.RV. V.; Arno H. O.; Gilles R.; Guy P.; Sophse A. and Pierre t. (2000). Study of water and sediment interactions in the Das velhas River, Brazil-Major and trace elements, 25 (2): 255-274 (2000).

Metawea, E.A.A. Monitoring and Evaluation of some chemical parameters associated with changing the effluent rates on El-Rahawy Drain and their impact on water quality of Rosetta branch. M.Sc. Thesis. Faculty of Science, Cairo University, Egypt (2009).

Mohamed, A.F. T. and Mostafa A. K.Physicochemical Characteristics of Water Quality in Lake Nasser Water, Global Journal of Environmental Research 3 (3): 141-148 (2009).

Mohamed, M. E.; Eman, A. M.; Gehad, G. M. and Mohamed, M. Y. Water quality of Rosetta branch in Nile delta, Egypt,_Suoseura-Finnish Peatland Society,_Helsinki ,Suo, 62(1): 31-37 (2011).

Nehad, K. and Shawky Z. S. Seasonal Variation and Interaction Between Rotifers and Bacteria in Rosetta Branch, River Nile, Egypt, Australian Journal of Basic and Applied Sciences, 7(2): 752-762 (2013).

Nicolae, C. Methods of reducing the corrosive potential of demineralization water, The $6^{\text {th }}$ edition of the Interdisciplinarity in Engineering International Conference, Petru Maior, University of Tîrgu Mures, Romania, $6^{\text {th }}$ edition,177-180 (2012).

Nor, S. M. and Wan, A. A. Chemical Oxygen Demand Reduction in Industrial Wastewater using Locally Isolated Bacteria, Proceedings of RAFSS (2010).

Pontius, F. Water Quality and treatment, $4^{\text {th }}$ edition. McGraw-Hill,Inc. US (1990).

Richard, Ainsworth, R. Ed. World Health Organization. Safe Piped Water: Managing Microbial Water Quality in Piped Distribution Systems.; IWA Publishing: London, UK (2004).

Roeder, RS.:Lenz, J.: Tarne, P.: Gebel, J.:Exner, M. And Szewzyk, U. (2010). Long-term effects of disinfectants on the community composition of drinking water biofilms. Internanonal,Journal, Hyg. Environ. Health 213:183-189 (2010). 
Saad, S.M.M.; El- Deeb A.E.; Tayel S.I. and Ahmed N.A.M. Haematological and histopathological studies on Clarias gariepinus in relation to water quality along Rossetta branch, River Nile, Egypt.. Egypt. Journal Exp. Biology (Zoology), 7(2): 223 - 233 (2011).

Sabae, S.Z. and Rabeh, S.A. Evaluation of the microbial quality of the river Nile waters at Damietta Branch, Egypt. Egyptian Journal of Aquatic Research, 33(1) 301-311(2007).

Safaa, M. E.; Hesham M. M.; Mervat A. A.; Essam H. A. and Mostafa A. E. Water Quality Assessment of River Nile at Rosetta Branch:Impact of Drains Discharge, Middle-East Journal of Scientific Research 12 (4): 413-423 (2012).

Shawky, Z. S. and Saleh A. R. Evaluation of the microbial quality of the River Nile waters at Damietta branch, Egypt, Egyptian Journal of Aquatic Research, 33 (1): 301-311 (2007).

Shehata, S.A. and Badr, S.A. Water Quality Changes in River Nile Cairo, Egypt,Journal of Applied Sciences Research, 6(9): 1457-1465 (2010).

Singh, M. R.; Gupta, A. and Beetswari, KH. Physico-chemical Properties of Water Samples from Manipur River System, India, Journal Applied Science. Environ. Manage, 14 (4): $85-89$ (2010).

Thamer, J. M.and Usama, B. M.Treatment and re-using of boiler blowdown in thermal electric power plants, Diyala Journal of Engineering Sciences ,First Engineering Scientific Conference College of Engineering -University of Diyala 22(23): 374-390 (2010).

Wafaa, M. Studies On The Relationship Between The Micro- Flora And Pollutants And Its Effect On The Nile Water Used In Electric Power Plants In Cairo , Thesis. Department of Biological and Physical Sciences Institute of Environmental Studies \&Research Ain Shams University (2006). 


\section{الملخص العربي}

دراسة على التغيير النوعى فى خواص مياه النيل والمياه المعالجة لمحطات توليد الكهرباء بمكانين مختلفين على نهر النيل.

\section{1فريالة عبد الحميد عبد الهادى،1 زينب محمد حسن خيرالله، 1شيماء محمد عبد السلام، \\ 2شيرين محمد عسكر}

1كلية البنات ،جامعة عين شمس،القاهرة ،مصر. 2المعامل الكيماوية المركزية،الثركة المصرية لنقل الكهرباء،القاهرة،مصر.

يهتم البحث بدر اسة التغيير الموسمي للخواص الفيزيائية و الكيميائية والبكتريولوجية بين مياه النيل الداخلة والمياه المرشحة لمحطتي توليد الكهرباء شبرا الخيمة (SH)، ودمياط (D). تراوحت قيم الكربون العضوي الكلي (TOC) بين أعلى قيمة و هي 29,55 - 18، و أقل قيمة و هي 28,95 - 21 ملجر ام/ لتر في (SH)، و (D) لمياه النيل على الترتيب. في

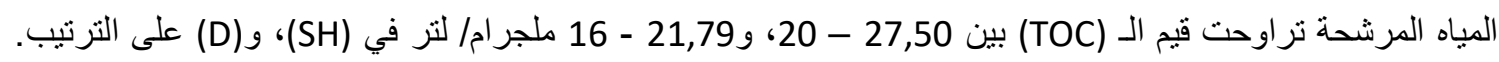
بلغ منوسط قيم التوصيل الكهربي أعلى من القيمة المسموح بها لمياه النيل في محطة (D) وهي 417 ملجرام/ لتر، ولكنها لاز الت في القيم المسموح بها للمياه المرشحة للمحطتين. تراوحت قيم متوسط الكبريتات لمياه النيل بين 39,50 - 43، و19,7 - 26 ملجر ام/ لتر في (SH)، و(D) على الترتيب، ولكنها زادت في المباه المرشحة لتصل إلى 77 - 56، و 34 - 41 ملجر ام/ لتر في (SH)، و (D) على الترتيب، وهي زادت عن القيم المسموح بها للمياه المرشحة للمحطتين. التحليل البكتريولوجي سجل أعلى قيمة لل. TC, FC, FS, Pseudomonas sp خلال الصيف لمياه النيل الداخلة للمحطنين، وقد انخفضت في المياه المرشحة للمحطنين. 